Innovation of Vocational Technology Education

Available online at http://ejournal.upi.edu/index.php/invotec

\title{
V
}

JURNAL UPI

\section{Production Unit of Vocational High School: Learning Resource and Enterpreneurships Place}

\author{
Herry Sumual \& Hendro M. Sumual \\ Universitas Negeri Manado, Indonesia
}

ARTICLE INFO

Article history:

Received 05 Juni 2016

Received in revised form 08 July

2016

Accepted 22 July 2016

Available online 31 August 2016

Keywords:

Learning resource

Enterpreneurships place

Production unit
A B S TR A C T

The purpose of this research is to develop an implementation model of production unit at Vocational High School that functions as learning resource and business place. The research method used is Research and Development. Sample units are 2 vocational high schools (public school) and 2 vocational high schools (private school). The results of the research are: The model of production unit at Vocational High School (VHS). This model has been tested limitedly with experts and party from Vocational High School and Department of Education and Culture of Manado City. Through this production model resulted, it can be suggested to party of school to manage the production unit that exists in each school very well as a form of services as well as to produce the goods.

Corresponding author:

herrysumual@yahoo.com

\section{Introduction}

Vocational education is education that prepare learners for work in addition to be able to continue their education to a higher level. Efforts by the government is expanding the number of vocational school in order to prepare the labor force so that the number of Indonesian population can be a Human Resources is not just a man, but the amount of attention to quality. Vocational high school massive increase in the number must be accompanied by educators, education and means good facilities and standardized, in addition to other educational standards. Vocational high school growth up to 2013 as many as 11.708 , the target of the Directorate of Vocational according Roadmap Vocational Education Development 2010-2014, in 2014 as many as 11.748 VHS with 4.512 .063 students and 219.000 teachers (Directorate of Vocational Guidance). In 2015 there were 12.809 Vocational high school with details 3.339 Vocational high school (Public School) status (26.07\%) and 9.470 Vocational high school (Private School) (73.93\%). The percentage of applicants for admission to vocational every year increase that is $11 \%$. In 2013 the number of applicants as much as 1.921 .919 candidates, who received 1.527 .778 students.

Growth in the number of vocational high school in Indonesia is not accompanied by the quality of graduates according to fields of expertise. The quality of vocational school graduates have not been able to 
fill a need in the business world and the industrial world, because the skills possessed not meet the standards required by the field of work. Central Statistics Agency data, in August 2015, a total of 12,65 percent of the unemployed are from Vocational high school, 10,32 percent of the Senior high school, 7.54 percent of the diploma, and 6,40 percent of the University. Chairman of the National Professional Certification Board (BNSP) Sumarna F Abdurahman said, many Vocational high school provide theory that is not in accordance with current practices in the industry. As a result, knowledge gained in vocational inapplicable. Director of the Education Division of Toshiba Sugiyanto Sutikno said it requires skilled personnel of the vocational school, but sometimes a workforce of vocational yet to master the latest tools that companies use them. "You could say, the tools provided in vocational 15 years lagged behind that we use. Technology informatics growing very rapidly, but it is not followed by an increase in vocational facilities" (CNN Indonesia, 10/07/2015).

\subsection{Decision by the Ministry}

To meet the expectations of the Ministry of Education and Culture will be the quality of vocational graduates then issue a decree of the Minister of Education and Culture No.0490/U/1992 on Vocational high school; every Vocational high school pursue the implementation of the production unit. The decision is a general law for all Vocational high school to establish a production unit in the school. So the existence of a production unit in Vocational high school is clear and strong. The function of the production unit is a place for student practice and also as a place for entrepreneurship in schools.

\subsection{Relevant research}

In this paper discussion will be published related research or relevant. Relevant research can be seen in Table 1.

Table 1. Relevant research

\begin{tabular}{|c|c|c|}
\hline No & Title / Authors & Research Discussion \\
\hline 1 & $\begin{array}{l}\text { Appraising Work- } \\
\text { Based Learning } \\
\text { Experiences of } \\
\text { Technical and } \\
\text { Vocational } \\
\text { (Teacher) } \\
\text { Educationand } \\
\text { Training (TVTET) } \\
\text { Programmes In } \\
\text { Nigeria / Ugochukwu } \\
\text { P.N. Amadi }\end{array}$ & $\begin{array}{l}\text { The skill emphasis in the implementation of technical and vocational } \\
\text { education and training (TVET) programmers demands that conscious and } \\
\text { concerted effort are made to put in place strategies that would guarantee } \\
\text { hand } \\
\text { - On learning experiences. Basically, a sure way of realizing these critical } \\
\text { objectives is by the instrument of work } \\
\text { - Based learning (WBL) which implies the establishment of a synergistic } \\
\text { relationship between TVET institution, business and industry as well as } \\
\text { community } \\
\text { - Based resources inventory. } \\
\text { This study has attempted to appraise the extent to which this synergy has } \\
\text { worked in the Nigeria TVET system, using the seven (7) Federal Colleges of } \\
\text { Education (Technical) in the South-Eastern geopolitical zone of the country } \\
\text { as study area. A total of } 200 \text { TVET instructors served as study sample while } \\
\text { a structured questionnaire was used in generating data relevant to the } \\
\text { study. Data analysis was based on the statistical tools of frequency, mean } \\
\text { and percentage. Findings indicated among other things that, all emphasis so } \\
\text { far is on the Student Industrial Work Experience Scheme (SIWES) leaving } \\
\text { other avenues or strategies almost unexploited. Such other strategies } \\
\text { identified by the study included: cooperative work experience programmer, } \\
\text { job shadowing, clinical work experience, youth apprenticeship programmer, } \\
\text { school based enterprises, internships, to list a few. Factors responsible for } \\
\text { this anomalous situation were indicated to include poor policy framework, } \\
\text { curricular defects, and inexperience on the part of administrators of TVET } \\
\text { programmers. Recommended important strategies emphasized awareness } \\
\text { creation through government industry forum, curriculum restructuring and } \\
\text { regular retraining of TVET instructors and teacher trainers. }\end{array}$ \\
\hline 2 & $\begin{array}{l}\text { Students' } \\
\text { Entrepreneurial } \\
\text { Behavior in the } \\
\text { Application of } \\
\text { 'Ekrenfatha' } \\
\text { Productive }\end{array}$ & $\begin{array}{l}\text { The purpose of the study is to observe students' entrepreneurial behaviors } \\
\text { in the implementation of entrepreneurship processes in production subjects. } \\
\text { The study applied production entrepreneurial teaching model to some } \\
\text { vocational high school students with their 'EkRenFaTiHa Catering' as their } \\
\text { project. The entrepreneur process was integrated in the catering production } \\
\text { subject and it consisted of the following aspects: Exploration, business }\end{array}$ \\
\hline
\end{tabular}




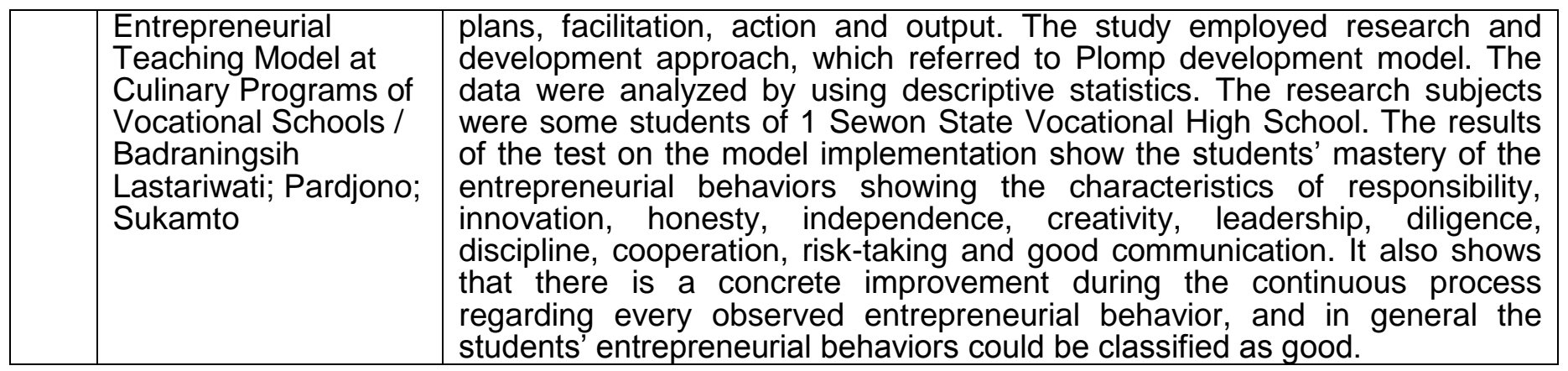

\section{Literature Review}

Production Unit is a program that was originally a unity in the Whole School Development program in Educational Development Program (Integrated Development School) or better known as PSS program (PPPGT Bandung, 1994). In general, the production unit is a process of business activities conducted within the school and business nature (profit-oriented) and conducted by the school community by empowering school resources that are owned and professionally managed (Direktorat Pendidikan Menengah Kejuruan, 1997: 2).

Suprapto (2001) production unit is "an activity that serves to produce goods and services by utilizing all available resources in school." According Sriyanto (1982) production unit is a "container for one or more activities of potential business and results can be marketed include goods and services. Meanwhile, according to Tawan Rosidi production unit at Vocational high school is a business activity aimed at obtaining added value / profit from operations. Good business activities or production activities, so expect no additional income for the school, which can support the Budget School (budgets). "Finch \& Crunkilton in Rusnani, Moerdiyanto, (2012): Learning and personal growth do not take place strictly within the confines of classroom or laboratory. Student develop skills and competence through a variety of learning activities and experiences that may not necessarily be counted as constructive credit for graduation.

The production unit is a business unit that has elements of academic and commercial, was held in the school organization that serves as a laboratory school and as a forum for entrepreneurship. Its results are used to support the financing of school operations and to increase the welfare of teachers and employees. According to Cunningham, Dawes \& Bennett in Zamzam Zawawi Paradise (2012) model of learning through action is the development strategy in the work-based learning. Further action learning approach is a model of learning in which an individual with the others in a small group to learn together to solve important problems, through the process and problem solving do they learn to resolve existing case.

This study aims to develop a model production unit Vocational high school in addition to being a laboratory also be a productive business in order to operate as a business institution in general so as to provide revenue to the production unit itself and can finance school operations better. The production units are developed and sustained will to support the quality of learning, in the end comes down to quality graduates.

\section{Research Method}

The design of the study is a Research and Development. Sample units are set purposive 2 Vocational high school (Public School) and 2 Vocational high school (Private School). Vocational high school (Public School) consists of SMK N 2 and SMK N 3, while the Vocational high school (Private School) consists of SMK Getsemani and SMK Harapan Generasi. Data collected through direct observation, interviews, and focus group discussion. Outcomes targeted in this study are: 1) The model production unit Vocational High School (VHS), 2) Guidelines for the management of production units, 3) Guide students to implement teaching with practices, 4) Guidelines for students' industry practice or internship. Analysis of the data used for testing is limited descriptive model of development Production Unit. 


\section{Result and Discussion}

\subsection{Result}

Having conducted limited testing by experts in their field then the model production unit which has been developed by the research team of revisions. The results of the revision can be seen in the figure below (Figure 1). Prior revised (Figure 2) there is one part of the production unit incorporated. The model can be described as follows:

\subsubsection{School resources}

School resources are beginning to be examined whether the school's resources are available for setting up manufacturing units. Elements of teachers, whether provided teachers who are competent to manage the production unit not only to practice or as a source of learning but it will be a function of the practice students to entrepreneurship as well be an attempt to earn money for the school in order to increase the operational costs of the school. In addition to the teacher whether facilities are also available that support the production unit. For the example engine production unit area of expertise, whether the available equipment of machines in the form of welding machine and others. All school resources both physical and non-physical equipment, namely teachers, employees and students is the main capital in the form of a production unit. Although the production unit has become a necessity in every vocational school but still there Vocational high school that do not have, because it has not provided adequate resources at the school. The results showed in Manado City there were only 4 of 32 Vocational high school (6 Vocational high school (Public School) 26 Vocational high school (Private School)) that unit production run well, although not considered good. From 6 Vocational high school (Public School) who runs a production unit only 2 Vocational high school. Vocational high school (Private School) admittedly rather successfully running a production unit only 2 schools.

\subsubsection{SWOT Analysis}

The next step should be considered in managing the production unit is a SWOT analysis in order to be more purposeful and focused areas of expertise what to set up a production unit.

\subsubsection{Establishment of Production Unit}

Having established production unit managers must make the planning, implementation guides, and guides the supervision or monitoring both for managers, students, and guidance for service users or customers. Free and SOP for students when entering the production units to practice, SOP service for customers. Management of the production unit must be made clear organizational structure if necessary administrative personnel recruited from outside the school. Free and SOP to maximize the function of the production units in order to grow like a business professional.

\subsubsection{Graduates have the Entrepreneurial Spirit}

Output of management in the production units are minimal graduates have an entrepreneurial spirit and also produce products or services. Through the activities of production unit skills of students trained to do something that produces a product, and are also trained to entrepreneurship, so that after their graduation, the graduates already have an entrepreneurial spirit. Expectations of the school, the graduates can open their own business for the field of expertise of each.

\subsubsection{Product/Service}

The products of the activities in the production unit is to produce a product or service. Products or services are sold to the public or customers. The example in the field of automotive expertise, the students can repair damaged cars or in the field of engine expertise that students can work on orders in the form of products fence or other welding. Students learn how to produce the goods/services that have economic value that sold in the market. This experience gives confidence for students to entrepreneurship in the future in addition to students and schools benefit financially.

\subsubsection{Institutional partner (partners)}

These institutions form of unit production partners, aim to assist in providing resource persons/trainers or facilities associated with activities in the production unit. In addition it should grant the form of grants from partner institutions. Role of partners here include helping units of production to market your 
products/services or also published the activity of production units. For model of development the production unit can be seen in Figure 1 and Figure 2.

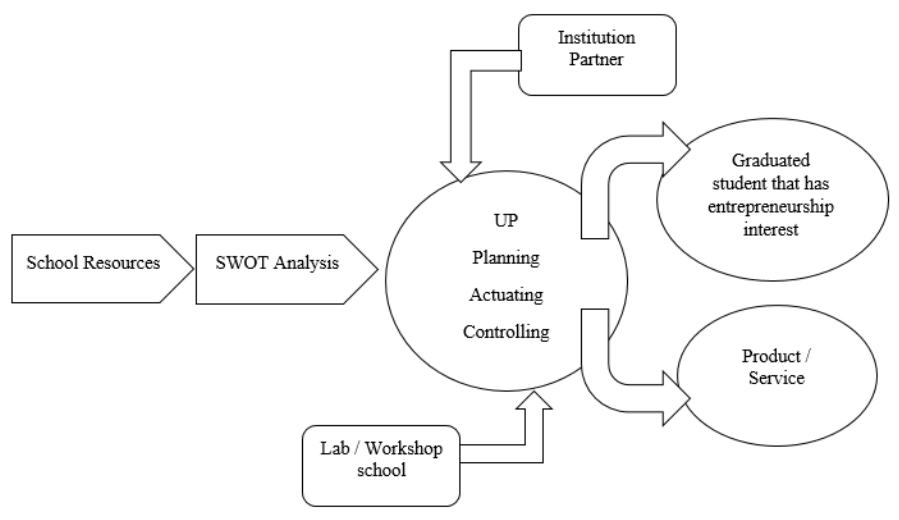

Figure 1. Model unit production revised

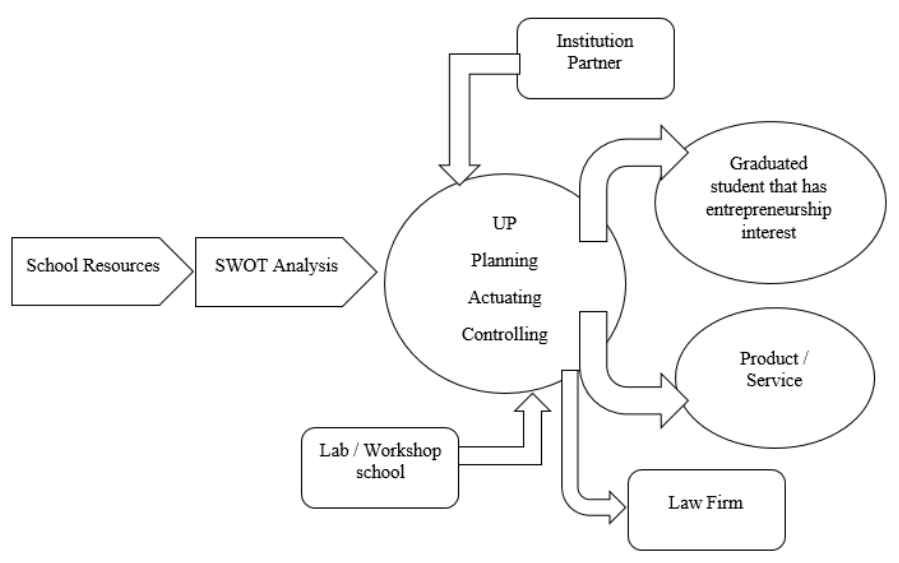

Figure 2. The production unit before the revised model

Model development Production Unit of the revised have been socialized at SMK Negeri 2 in the city of Manado. The results showed that in 4 Vocational High School (VHS) as unit of the sample existing production units have not been managed into a professional business unit.

\subsection{Discussion}

Unit Production at Vocational High School is an activity that serves to produce goods and services by utilizing all available resources in the school and its environment. The production unit in Vocational high school targeted research is not entirely run within the meaning operates as the purpose of the production unit. Production unit functions only as a student practices with respect to subjects productive in school. Activities to lead to an effort to earn the school does not yet appear. Moreover, the existing equipment in the production unit is outdated, meaning the need to procure more modern. As the main purpose of Vocational high school (SMK/MAK) is to prepare graduates who are ready to work in the field. In connection with the preparation of this work force, are explicitly mentioned in Government Regulation No.29 of 1990 on article 29, paragraph 2, that: "to prepare vocational students into the workforce, the Vocational high school can set up production units that operate in a professional manner". If it is said, the professionals in the management of the production unit must be managed professionally like a business entity. This means that there is good planning for practical activities and business activities. In addition it should be supported with modern equip-ment that is aligned with the industry in the field.

For that, Vocational high school must be able to provide a learning experience for the student to master competencies in a professional and productive use of supporting tools up to date. In addition, students also have to be taught entrepreneurship in practice so that graduates are not only job seekers but also can be job creators. The entrepreneurial competencies can be acquired through learning in the unit of production/services in schools. Benefits unit of production/services in Vocational high school is as a source 
of student learning and educational funding. The financial benefits unit of production/services may be one source of funding vocational education given the high cost of the practice. Unit production/services the school can be a source of learning and education funding it needs to be managed professionally.

Results Rusnani study (2012) showed that the implementation of learning programs Production Unit/Services in Vocational high school (Public School) Group business and management in Banjarmasin, including effective that $(36.6 \%)$. This indicates that the unit production as a source of learning can play a role to contribute to the student competency.

The production unit in school is limited to conducting handle projects from outside the school because they do not have institutions such as CV, or PT. The production unit can't be upgraded into enterprises since these institutions belong to the school, the reason the school is not a pursuit of profit.

The study was limited to planning the development model Production Unit, and tested on a limited basis in one of Vocational high school and has not tested the effectiveness of the use of the model. Suggestions for further research, namely the implementation of the use of the model production unit to Vocational high school that already has a production unit/service.

\section{Conclusion}

Based on the results of this study, the writer comes to the conclusion that:

1) Unit production/services that functions as a learning resource and a source of school revenue needs professionally managed.

2) The production unit as an entrepreneurs unit should be supported by documents such as guidelines and SOPs that can be measured lower standards.

3) Vocational high school that has no production unit, the model generated in this study becomes an alternative for its establishment.

It is suggested that to schools that already have a production unit that is professionally managed and should have guidelines and SOPs in operation.

\section{References}

Badraningsih, L., Pardjono \& Sukamto. Students' Entrepreneurial Behavior in the Application of 'Ekrenfatha' Productive Entrepreneurial Teaching Model at Culinary Programs of Vocational Schools. Research and Evaluation in Education 2 (1): 53-70.

Drucker, P.E. 1985. Innovation and Enterpreneurship. New York: McGraw Hill Book.

Mulyasa, E. 2002. Manajemen Berbasis Sekolah; Konsep, Strategi, dan Implementasi. Bandung: PT Remaja Rosdakarya.

Nolker, H. \& Schoenfeldt, E. 1983. Pendidikan Kejuruan; Pengajaran, Kurikulum, Perencanaan. Jakarta: PT Gramedia.

Pakpahan, J. 1997. Strategi Pengembangan Unit Produksi di Sekolah Menegah Kejuruan. Direktorat Pendidikan Menengah Kejuruan (DEPDIBUD): Jakarta.

Rusnani \& Moerdiyanto. 2012. Artikel Pelaksanaan Unit Produksi Pada Sekolah Menengah Kejuruan Negeri Kelompok Bisnis Dan Manajemen Di Banjarmasin. UNY: Yogyakarta.

Sumual, H. 2009. Laporan Penelitian Model Perencanaan Terpadu Pengembangan Unit Produksi SMK di Manado.

Suryana, 2003. Kewirausahaan. Salemba: Jakarta.

Tabrani, A. 1993. Manajemen Pendidikan. Bandung: Media Pustaka.

Tilaar, H.A.R. 2001. Manajemen Pendidikan Nasional, Kajian Pendidikan Masa Depan. Bandung: PT Remaja Rosdakarya. 